ACTA UNIVERSITATIS WRATISLAVIENSIS

No 4077

Studia nad Autorytaryzmem i Totalitaryzmem 43, nr 3

Wrocław 2021

https://doi.org/10.19195/2300-7249.43.3.15

\author{
MAŁGORZATA SZWEJKOWSKA \\ ORCID: 0000-0003-3714-4860
}

Akademia Ekonomiczno-Humanistyczna w Warszawie m.szwejkowska@vizja.pl

\title{
Przedterminowe zwolnienie z kary pozbawienia wolności skazanych za ludobójstwo, zbrodnie przeciwko ludzkości i wojenne na mocy orzeczeń międzynarodowych trybunałów karnych ad hoc oraz ich sukcesora w postaci Mechanizmu Rezydualnego ONZ
}

Słowa kluczowe: przedterminowe zwolnienie, ludobójstwo, zbrodnie wojenne, przestępstwa przeciwko ludzkości, Międzynarodowy Trybunał Karny dla byłej Jugosławii, Międzynarodowy Trybunał dla Rwandy, Mechanizm Rezydualny ONZ.

\author{
EARLY RELEASE FROM IMPRISONMENT OF PERSONS CONVICTED \\ OF GENOCIDE AND WAR CRIMES BY AD HOC INTERNATIONAL TRIBUNALS \\ IN CRIMINAL LAW AND THEIR SUCCESSOR — THE RESIDUAL MECHANISM OF UN
}

Abstract

In the last decade of the 20th century, a war in the former Yugoslavia broke out, once again making Europe a witness to an armed conflict. Almost at the same time, another local ethnic bloodshed started, but this time in distant Africa — in Rwanda. Both these events included the most horrifying international crimes against humanity: genocide and war crimes. To prosecute the most important commanding figures involved in these conflicts and hold them criminally responsible, two ad hoc United Nations tribunals were created: International Criminal Tribunal for the former Yugoslavia in Hague and International Criminal Tribunal for Rwanda in Arusha. They finished their operation in 2017 and 2015, respectively. The tasks of conducting and completing all ongoing proceedings, including law enforcement, after the completion of their mandates have been entrusted to the UN International Residual Mechanism. 
One of the crucial assignments of the tribunals and later the Redisual Mechanism was to deal with the request on behalf of the convicted for granting them early release. Although none of the statutes of the aforementioned courts provided any ground for early release, soon it was accepted that both tribunals, as well as their successor, were entitled to proceed despite this issue. As soon as in 2001, the first convict was granted early release, but with no conditions. It is estimated that, to date, more than $2 / 3$ of all convicted by the Tribunals have been released before the termination of their sentence. This should raise the question of how to rehabilitate that kind of offender, convicted of genocide, war crimes, or crimes against humanity, to ensure they do not pose a threat to society anymore. Especially since the offenders serve their punishment outside the country of their origin - meaning, different rules apply according to the domestic law regulation of the state that voluntarily agreed to enforce the sentence.

This article analyzes the juridical approach of the tribunals and the Residual Mechanism on the issue of early release of the convicts involved in the armed conflicts in the former Yugoslavia and Rwanda.

Keywords: early release, genocide, war crimes, crimes against humanity, UN International Criminal Tribunals for the former Yugoslavia and Rwanda, UN International Residual Mechanism.

\section{Wprowadzenie}

Ostatnia dekada XX wieku to czas, w którym rozegrały się jedne z najtragiczniejszych i najbardziej brutalnych konfliktów zbrojnych od czasu zakończenia wojny światowej. Jeden z nich miał miejsce w samym środku Europy — na Bałkanach, drugi zaś w rozrywanej wewnętrznymi walkami Afryce - w Rwandzie. Oba przeszły do historii jako synonimy najbardziej odrażających i nieludzkich czynów zabronionych, do których wybuchu doprowadziły autorytarne systemy rządów prezydenckich: w Rwandzie - Juvénala Habyarimana, w Serbii zaś Slobodana Miloševicia. Procesy w przedmiocie ustalenia odpowiedzialności karnej osób uczestniczących w tych wydarzeniach, a oskarżonych o dopuszczenie się najcięższych zbrodni przeciwko pokojowi, ludzkości albo wojennych, skupiły na sobie uwagę nie tylko światowej opinii publicznej, stanowiąc przedmiot doniesień medialnych, lecz zainicjowały także dyskusję w naukowych środowiskach prawniczych. Ta ostatnia koncentrowała się wokół dotychczasowych mechanizmów gwarancyjnych prawa międzynarodowego w zakresie zapobiegania krwawym konfliktom zbrojnym. Społeczność międzynarodowa okazała się całkowicie nieprzygotowana na oba te wydarzenia, a ich skala i bezmiar okrucieństwa zakwestionowały skuteczność działań ONZ w rozwiązywaniu konfliktów lokalnych $^{1}$. Historia konfliktów zbrojnych w Rwandzie i byłej Jugosławii dobitnie pokazuje, że mimo dokonującego się postępu cywilizacyjnego i przyjmowana na płaszczyźnie prawa międzynarodowego licznych aktów prawnych regulujących

${ }^{1}$ R. Śliwa, Międzynarodowy trybunat do spraw ścigania osób odpowiedzialnych za łamanie międzynarodowych praw człowieka na terytorium bytej Jugosławii poczqwszy od $1991 \mathrm{r}$., [w:] Batkany u progu zjednoczonej Europy, red. P. Czubik, Kraków 2008, s. 97. 
odpowiedzialność za zbrodnie wojenne, ludobójstwa czy przeciwko pokojowi czynom tym nie udaje się w pełni zapobiegać ${ }^{2}$.

W przeciwieństwie do procesów karnych dotyczących przypisania odpowiedzialności zbrodniarzom uczestniczącym w przedmiotowych konfliktach zagadnienia związane $\mathrm{z}$ wykonywaniem wobec nich sankcji karnych orzeczonych przez międzynarodowe trybunały karne oraz Mechanizm Rezydualny nie są już szczególnym przedmiotem zainteresowania ani opinii publicznej, ani przedstawicieli doktryny prawa międzynarodowego czy prawa karnego.

Celem artykułu jest przybliżenie zasad stosowania przedterminowego zwolnienia przez międzynarodowe trybunały karne ad hoc dla byłej Jugosławii oraz dla Rwandy, powołane przez społeczność międzynarodową do osądzenia sprawców, którzy uczestniczyli w tych konfliktach zbrojnych ${ }^{3}$. Ich zadania od kilku lat kontynuuje Mechanizm Rezydualny. W kontekście polskim jest to zagadnienie o tyle aktualne, że w zakładzie karnym w Piotrkowie Trybunalskim przebywa czterech osadzonych, osądzonych prawomocnie przez Międzynarodowy Trybunał Karny dla byłej Jugosławii. Są to pierwsi zbrodniarze wojenni odbywający karę izolacyjną w Polsce od czasów Ericha Kocha. Przy czym jeden z nich — generał w armii Republiki Serbskiej Radislav Krstić, skazany między innymi za zbrodnie ludobójstwa w Srebrenicy — nabył uprawnienia do ubiegania się o warunkowe przedterminowe zwolnienie stosownie do dyspozycji art. $77 \mathrm{i}$ n. kodeksu karnego i z tego tytułu złożył wniosek do polskiego sądu penitencjarnego o zastosowanie wobec niego tej instytucji.

\section{Powstanie międzynarodowych trybunałów karnych do osądzenia zbrodni popełnionych podczas konfliktów zbrojnych w byłej Jugosławii oraz Rwandzie}

Międzynarodowy Trybunał Karny dla byłej Jugosławii (z ang. w skrócie ICTY) powstał na mocy rezolucji Rady Bezpieczeństwa ONZ z dnia 25 maja 1993 roku nr 827. Podstawą działań Rady był rozdział VII Karty Narodów Zjednoczonych i rezolucja $\mathrm{nr} 808$ z 22 lutego 1993 roku. Był to pierwszy od czasów powojennych międzynarodowy trybunał karny ad hoc. Zgodnie ze swoim statutem został powołany do osądzenia ludobójstwa, zbrodni przeciwko ludzkości oraz zbrodni wojennych popełnionych na terytorium byłej Jugosławii, począwszy od 1991 roku.

2 A. Spychalska, Mechanizmy zbrodni ludobójstwa na przykladzie Rwandy, [w:] Varia doctrinalia, red. Ł. Machaj, Wrocław 2012, s. 98.

3 M. Olesiuk-Okomska, Przestępstwa międzynarodowe podlegajace rozpoznaniu przez międzynarodowe trybunaty karne, „International Journal of Legal Studies” 2017, nr 2, s. 76. 
Międzynarodowy Trybunał Karny dla Rwandy (z ang. w skrócie ICTR) rozpoczął procedowanie na podstawie rezolucji nr 955 Rady Bezpieczeństwa z dnia 8 listopada 1994 roku. Jego funkcjonowanie opierało się na koncepcji wypracowanej przy powoływaniu Międzynarodowego Trybunału do spraw byłej Jugosławii ${ }^{4}$. Oba trybunały działały na podstawie bardzo zbliżonych, niemal identycznych statutów oraz Reguł Postępowania i Dowodowych. Przedmiotowe sądy powstały, jak już zaznaczono, jako organy o charakterze temporalnym $(\text { ad hoc })^{5}$, nie określono jednak przy ich powoływaniu terminu zakończeniach ich działalności. Geneza obu sądów tak jak innych tego typu organów powołanych ad hoc wynikała $\mathrm{z}$ faktu, że krajowe systemy wymiaru sprawiedliwości obu tych państw - byłej Jugosławii czy Rwandy - z pewnością nie poradziłyby sobie $\mathrm{z}$ bezstronnym osądem zarzutów stawianym zbrodniarzom wojennym, a następnie z procesem wykonywania wobec nich w sposób bezstronny orzeczonej kary.

Prekursorem obu trybunałów były sądy karne, które podjęły pracę po zakończeniu drugiej wojny światowej - Międzynarodowy Trybunał Wojskowy w Norymberdze ${ }^{6}$ oraz Międzynarodowy Trybunał Wojskowy dla Dalekiego Wschodu w Tokio. Działalność obu, powołanych przez Sprzymierzone Siły Wielkiej Brytanii, Stanów Zjednoczonych, Francji oraz Związku Radzieckiego, sprowadzała się do osądzenia zabronionych metod prowadzenia wojny wymienionych między innymi w treści konwencji haskich z 1907 roku oraz konwencji genewskich z 1929 roku. Oskarżeni odpowiadali za trzy rodzaje zbrodni: zbrodnie wojenne, przestępstwa przeciwko pokojowi oraz przestępstwa przeciwko ludności. Międzynarodowy Trybunał Wojskowy dla Dalekiego Wschodu (tak zwany tokijski) działał według pryncypiów wypracowanych dla trybunału w Norymberdze w okresie od 29 kwietnia 1946 do dnia 12 listopada 1948 roku$^{7}$. Jako że trybunał norymberski rozpoczął swoją pracę jako pierwszy, działalność trybunału tokijskiego zeszła nieco na dalszy plan ${ }^{8}$. Stąd też powszechnie przyjmuje się, że to powstanie Trybunału Wojskowego w Norymberdze było punktem wyjścia do rozwoju prawa międzynarodowego karnego. To ten trybunał stwierdził, że prawo międzynarodowe kreuje prawa i obowiązki także wobec osób fizycznych, za naruszenie zaś norm prawa międzynarodowego jednostki mogą odpowiadać. Jak wskazano

4 A. Spychalska, op. cit., s. 94.

5 D. Heidrich, Przyszłość międzynarodowych trybunałów karnych ad hoc. Strategie zakończenia oraz rozwiązania rezydualne, ze szczególnym uwzględnieniem Międzynarodowego Trybunału Karnego dla byłej Jugosławii, „Studia Europejskie” 2013, nr 3, s. 162.

${ }^{6}$ Powstał na mocy decyzji Sił Sprzymierzonych z dnia 20 listopada 1945 r. i funkcjonował do 1 października 1946 r., w okresie swojego funkcjonowania skazał 12 oskarżonych na karę śmierci, 3 na karę dożywotniego pozbawienia wolności oraz 4 na karę pozbawienia wolności od 10 do 20 lat.

7 W tym czasie trybunał skazał 5 zbrodniarzy na karę śmierci, 16 na karę dożywotniego pozbawienia wolności i dwóch oskarżonych na kary 7 i 20 lat pozbawienia wolności.

${ }^{8}$ K. Karski, D. Świętońska, Proces przed Międzynarodowym Trybunatem Wojskowym dla Dalekiego Wschodu i jego miejsce w świadomości historycznej Japończyków, „Gdańskie Studia Azji Wschodniej" 2013, nr 4, s. 8. 
w wyroku trybunału norymberskiego z dnia 1 października 1946 roku: „to ludzie, a nie abstrakcyjne jedności popełniają zbrodnie, które wymagają represji jako sankcji międzynarodowej"9. Zaaprobowano także podział najpoważniejszych przestępstw popełnianych podczas działań wojennych na przestępstwa przeciwko pokojowi, przeciwko ludzkości oraz zbrodnie wojenne ${ }^{10}$. Podkreślenia wymaga w kontekście tematu niniejszego opracowania, że ani trybunał w Norymberdze, ani tokijski nie stosowały instytucji przedterminowego zwolnienia skazanych, łagodzono natomiast orzeczone sankcje karne, zamieniając karę śmierci na dożywotnie pozbawienie wolności, a tę karę z kolei na sankcje w postaci terminowej kary pozbawienia wolności.

ONZ już w 1948 roku zleciła Komisji Prawa Międzynarodowego zbadanie zagadnienia dotyczącego powołania międzynarodowego sądu karnego przeznaczonego do rozpoznawania spraw o zbrodnie przeciwko ludzkości lub innych czynów o analogicznej wadze gatunkowej popełnionych przez jednostki lub grupy osób, jednak efekty tych prac wyłaniały się bardzo powoli ${ }^{11}$. Inną pochodną działań trybunałów w Norymberdze i w Tokio było jednogłośne przyjęcie przez Zgromadzenie Ogólne ONZ w 1948 roku Konwencji w sprawie karania i zapobiegania zbrodni ludobójstwa ${ }^{12}$. Konwencja ta stwarzała możliwość tworzenia trybunałów karnych ad hoc. Okres zimnej wojny, który później nastąpił, spowodował jednak, że dalsze prace w tym zakresie zostały zaniechane. Ostatecznie stały sąd międzynarodowy karny powołano do życia na mocy Statutu Rzymskiego, który reguluje funkcjonowanie Międzynarodowego Trybunału Karnego w Hadze ${ }^{13}$.

\section{Cele i zasady funkcjonowania trybunałów ad hoc powołanych do osądzenia zbrodni w byłej Jugosławii oraz w Rwandzie oraz zastąpienie ich przez Mechanizm Rezydualny ONZ}

W odróżnieniu od trybunałów w Norymberdze i w Tokio trybunały do spraw osądzenia zbrodni popełnionych na terenie byłej Jugosławii lub w ramach wojny

9 Cyt. za: K.M. Pospieszalski, Wyrok Norymberski (zasady prawne), „Przegląd Zachodni” 1948, nr 2, s. 134.

10 R. Śliwa, op. cit., s. 99.

11 D. Gozani, Beginning to learn how to end: lessons on completion strategies, Residual Mechanism and legacy considerations from ad hoc international tribunals to the international criminal court, „Loyola of Los Angeles International and Comparative Law Review” 4, 2015, nr 1, s. 332.

12 R. Śliwa, op. cit., s. 99.

13 Międzynarodowy Trybunał Karny w Hadze jednak nie mógł przejąć do prowadzenia spraw o zbrodnie popełnione przed dniem 1 lipca 2002 r., to jest przed dniem wejścia w życie Rzymskiego Statutu Międzynarodowego Trybunału Karnego sporządzonego w Rzymie dnia 17 lipca 1998 r., Dz.U. z 2003 r. Nr 78, poz. 708. 
domowej w Rwandzie ${ }^{14}$ zostały powołane do rozpoznania spraw o przestępstwa popełnione $\mathrm{w}$ ramach regionalnego konfliktu, nie zaś globalnego. Ponadto powstały na mocy konsensusu międzynarodowego, a nie z woli zwycięskiej strony konfliktu zbrojnego. Oba sądy międzynarodowe miały jednak skoncentrować się, analogicznie do zakresu działań ich historycznych odpowiedników, wyłącznie na pociąganiu do odpowiedzialności karnej najwyższych rangą przywódców wojennych podejrzewanych o zbrodnie ludobójstwa, wojenne czy przeciwko pokojowi, pozostawiając kwestię osądzenia sprawców niższego szczebla sądownictwu krajowemu. $\mathrm{Z}$ tego względu od początku zakładano, że ten rodzaj sądów karnych (tak zwanej drugiej generacji) będzie pełnił swoje funkcje wyłącznie temporalnie.

W swoim pierwotnym założeniu rola trybunałów nie miała sprowadzać się wyłącznie do osądzenia sprawców wymienionych zbrodni, promując zasady sprawiedliwości wypracowane przez społeczność międzynarodową ${ }^{15}$, lecz także miały one zachęcać strony tego krwawego konfliktu do pojednania i aktywnie działać na rzecz utrzymania pokoju w regionie. Można jednak zaryzykować stwierdzenie, że brakuje dowodów na jakiekolwiek sukcesy w tej sferze. Opisana polityka penitencjarna obu przedmiotowych sądów też nie pozostała bez wpływu na negatywną ocenę ich działania w analizowanym zakresie.

Sądy międzynarodowe ad hoc zostały powołane ponadto do oceny postępów $\mathrm{w}$ resocjalizacji skazanych, co musiało dokonywać się na etapie wykonywania orzeczonej wobec nich długoterminowej kary pozbawienia wolności. Trzeba zaznaczyć, że w swoich uzasadnieniach w zakresie dotyczącym wymierzanej sprawcom kary trybunały bardzo często nawiązywały do resocjalizacyjnego celu, jaki należałoby osiągnąć wobec skazanych przez wykonywanie kary izolacyjnej ${ }^{16}$. Na czym jednak ów proces resocjalizacji (z ang. rehabilitation) miałby in concreto polegać, tego nigdy trybunały nie definiowały, pozostawiając wypracowanie stosownych mechanizmów oddziaływania państwom przyjmującym skazanych do odbycia na ich terytorium kary pozbawienia wolności.

Zarówno Trybunał Karny dla byłej Jugosławii, jak i Trybunał dla Rwandy mogły orzekać kary pozbawienia wolności aż do kary dożywotniego pozbawienia

14 Odpowiednio: Międzynarodowy Trybunał Karny do Ścigania Osób Odpowiedzialnych za Poważne Naruszenia Międzynarodowego Prawa Humanitarnego Popełnione na Terytorium Byłej Jugosławii oraz Międzynarodowy Trybunał Karny do Ścigania Osób Odpowiedzialnych za Ludobójstwo i inne Poważne Naruszenia Międzynarodowego Prawa Humanitarnego Popełnione na Terytorium Rwandy oraz Obywateli Rwandy Odpowiedzialnych za Ludobójstwo i inne Takie Naruszenia Popełnione na Terytorium Sąsiednich Państw.

15 Rola obu trybunałów okazała się przełomowa w tym zakresie chociażby dlatego, że po raz pierwszy w ramach prac obu sądów uznano masowe zgwałcenia i inne formy przemocy seksualnej za formy prowadzenia działań wobec określonej grupy etnicznej; por. A. Domagała, Ściganie i karanie sprawców gwałtu i przemocy seksualnej podczas konfliktów zbrojnych po zakończeniu zimnej wojny, ,Wrocławskie Studia Politologiczne” 2011, nr 12, s. 209.

16 B. Hola et al., Does remorse count? ICTY Convict's reflections on their crimes in early release decisions, „International Criminal Justice Review” 28, 2018, nr 4, s. 349-350. 
wolności włącznie, za przestępstwa wymienione: w art. 2-5 Statutu Trybunału dla byłej Jugosławii oraz w art. 2-4 Statutu Trybunału dla Rwandy (art. 1 § 1-3 Statutu Mechanizmu Rezydualnego w zw. z art. 125 lit. a Reguł Postępowania i Dowodowych Mechanizmu ${ }^{17}$ ). Zakresem kognicji zostały zatem objęte czyny ludobójstwa, zbrodnie przeciwko ludzkości oraz zbrodnie polegające na ciężkim naruszeniu konwencji genewskich z 1949 roku lub praw i zwyczajów wojennych.

Stosownie do treści art. 27 Statutu Międzynarodowego Trybunału Karnego dla byłej Jugosławii - odpowiednio art. 26 Statutu Międzynarodowego Trybunału dla Rwandy - wykonywanie kary pozbawienia wolności wobec skazanych przez ten organ odbywa się na terytorium jednego z państw, które zgłosiły Radzie Bezpieczeństwa ONZ dobrowolnie gotowość do przyjęcia tego rodzaju osadzonych. Przystąpienie do umowy może dotyczyć przyjęcia do wykonania kary na przykład wobec jednego skazanego, a zatem nie musi dojść do podpisania w tym zakresie ogólnej umowy o przyjmowaniu tego rodzaju skazanych do wykonania wobec nich kary na terytorium państwa-strony. Zgodnie z przytoczonymi przepisami warunki odbywania kary pozbawienia wolności określa system prawny państwa, na którego terytorium kara pozbawienia wolności jest wykonywana. Nadzór i kontrolę nad procesem jej odbywania zachowuje jednak odpowiedni trybunał. Rozwiązanie to przyjęto ze względu na to, że oba trybunały ad hoc nie dysponowały własnymi jednostkami penitencjarnymi, w których skazani na kary pozbawienia wolności mogliby odbywać orzeczoną wobec nich karę.

Stwierdzić należy, iż trybunały ad hoc w praktyce od początku XXI wieku zaczęły stosować wobec skazanych zbrodniarzy instytucję przedterminowego zwolnienia z kary pozbawienia wolności, jakkolwiek żaden z przepisów statutowych, na podstawie których trybunały wypełniały swoją misję, takiej instytucji nie przewidywał. Statuty przewidywały wyłącznie możliwość zastosowania prawa łaski albo zamiany kary na sankcję łagodniejszego rodzaju lub darowanie jej części. W myśl art. 28 Statutu Trybunału Karnego dla byłej Jugosławii (odpowiednio art. 27 Statutu Trybunału dla Rwandy), jeżeli zgodnie z ustawodawstwem państwa, na którego terytorium sprawca odbywa karę, jej zamiana na karę łagodniejszego rodzaju lub darowanie części kary (ang. commutation of sentence) bądź ułaskawienie (ang. pardon) są możliwe, powinno to zostać zgłoszone Prezesowi Trybunału, który, po konsultacji z sędziami Trybunału, podejmuje decyzję $\mathrm{w}$ tym przedmiocie. Przepisy te jednak nie odnosiły się expressis verbis do udzielania przedterminowego zwolnienia z kary pozbawienia wolności, która to instytucja co do zasady wymaga określenia okresu próby oraz nie oznacza skrócenia wymiaru orzeczonej wobec skazanego kary pozbawienia wolności.

Pierwszymi skazanymi, którym Międzynarodowy Trybunał dla byłej Jugosławii udzielił przedterminowego zwolnienia, byli Zlatko Aleksovski (listopad

${ }^{17}$ Reguły Postępowania i Dowodowe Mechanizmu Rezydualnego, MICT/1/Rev.7, https:// www.irmct.org/sites/default/files/documents/MICT-1-Rev.6\%20\%28E\%29.pdf (dostęp: 12.12.2020). 
$2001)^{18}$, Dragan Kolundzija (grudzień $2001^{19}$ ) oraz Milojica Kos (lipiec $2002^{20}$ ). Zarówno Kolundzija, jak i Kos odbywali orzeczoną wobec nich karę pozbawienia wolności w areszcie w Hadze. W tamtym czasie żaden przepis prawny Statutu Trybunału czy Reguł Postępowania i Dowodowych nie regulował sytuacji, w której skazani przebywający w tym areszcie mogą ubiegać się o przedterminowe zwolnienie. Opinia o zachowaniu i postawie skazanych podczas odbywania kary została przygotowana przez areszt w Hadze. Podejmując pozytywną decyzję w tym przedmiocie, Trybunał dla byłej Jugosławii nie nałożył żadnych obowiązków probacyjnych i nie określił okresu próby, stwierdzając że nie jest do tego uprawniony. Trybunał dla byłej Jugosławii, podejmując te decyzje, pośrednio uznał przedterminowe zwolnienie za rodzaj ułaskawienia (pardon) lub zamiany kary na łagodniejszą bądź też darowania jej części (commutation of sentence), które to instytucje, jak już podniesiono, przewidziano w dyspozycji art. 28 Statutu przedmiotowego trybunału. Normy prawne nie wskazywały jednak na możliwość określenia okresu próby oraz nakładania jakichkolwiek obowiązków na skazanych zwalnianych przedterminowo przez Trybunał dla byłej Jugosławii.

Już tu należy jednak stwierdzić, że ułaskawienie niemal we wszystkich systemach prawnych uważane jest za prerogatywę głowy państwa. Z kolei posiłkując się definicjami warunkowego zwolnienia zawartymi w aktach prawa międzynarodowego, przykładowo treścią art. 1 (1) rekomendacji $\mathrm{nr} 22$ z 2003 roku Komitetu Ministrów Rady Europy w sprawie zwolnienia warunkowego implicite wyłączono instytucję ułaskawienia i amnestii ${ }^{21}$, należy stwierdzić, że terminem „Zwolnienie warunkowe” określono środek probacyjny realizowany w warunkach powrotu sprawcy do społeczeństwa, po odbyciu przez niego określonej części kary w warunkach izolacji penitencjarnej. Istotą tej instytucji jest określenie przez sąd okresu próby oraz nałożenie na sprawcę przestępstwa obowiązków, tak aby zweryfikować trafność postawionej wobec niego pozytywnej prognozy kryminologicznej, opierającej się na przekonaniu, że jego dalszy pobyt w jednostce penitencjarnej nie jest już konieczny. Minimalny okres kary lub określona ułamkowo część kary, które muszą być odbyte przed udzieleniem warunkowego zwolnienia (quantum odbytej kary), nie powinny być tak długie, by uniemożliwić osiągnięcie celów warunkowego zwolnienia. Warunkowe przedterminowe zwolnienie nie polega jednak, jak już to zaznaczono, na darowaniu jakiejkolwiek

$18 \mathrm{https}: / /$ www.icty.org/x/cases/aleksovski/cis/en/cis_aleksovski_en.pdf (dostęp: 1.04.2020).

19 The President of the ICTY grants Release of Dragan Kolundzija. | International Criminal Tribunal for the former Yugoslavia, https://www.icty.org/en/press/president-icty-grants-release-dra gan-kolundzija (dostęp: 1.04.2020).

20 The President of the ICTY orders release of Milojica Kos | International Criminal Tribunal for the former Yugoslavia, https://www.icyty.org/en/press/president-icty-orders-release-milojica-kos (dostęp: 1.04.2020).

21 Zalecenie nr R (2003)22 Komitetu Ministrów do Państw Członkowskich Rady Europy W sprawie zwolnienia warunkowego. 
części kary pozbawienia wolności. Polega wyłącznie na przyjęciu fikcji prawnej, że kara została przez skazanego odbyta w całości.

W Europie w większości państw jako quantum odbycia kary pozbawienia wolności uprawniającej do ubiegania się o dobrodziejstwo przedterminowego zwolnienia zazwyczaj przyjmuje się wykonanie dwu trzecich kary pozbawienia wolności. Jednakże występują też takie systemy penitencjarne, na przykład polski czy austriacki, dopuszczające stosowanie tego dobrodziejstwa zasadniczo już po odbyciu połowy kary ${ }^{22}$.

Trybunały przyjęły jednak odmienną politykę dotyczącą spełnienia warunków formalnych do uzyskania przez skazanych przedterminowego zwolnienia. Otóż Trybunał dla byłej Jugosławii przyjął koncepcję odbycia dwu trzecich kary pozbawienia wolności, Trybunał zaś dla Rwandy trzech czwartych kary pozbawienia wolności ${ }^{23}$. W orzecznictwie obu trybunałów przeważało zapatrywanie, że przedterminowe zwolnienie nie może łączyć się z ustanawianiem obowiązków probacyjnych ani oznaczania okresu próby, gdyż brakuje ku temu podstaw prawnych.

Wśród okoliczności świadczących o pozytywnym przebiegu procesu resocjalizacji oba trybunały wskazywały: przyznanie się do winy i przyjęcie odpowiedzialności za popełnione zbrodnie, refleksje krytyczne dotyczące popełnionych czynów, wykształcenie się odczucia empatii wobec pokrzywdzonych, okazanie skruchy i wyrażenie prośby o przebaczenie, pozytywne nastawienie wobec osób odmiennej niż sprawca narodowości, dobrowolny i efektywny udział w oddziaływaniach resocjalizacyjnych prowadzonych w jednostkach penitencjarnych, pozytywną prognozę kryminologiczną wobec sprawcy ${ }^{24}$. Przedmiotowa lista nie ma charakteru wyczerpującego, jest tylko pewnego rodzaju egzemplifikacją ${ }^{25}$.

Podsumowując funkcjonowanie trybunałów, podkreślenia wymaga, że w czasie ćwierćwiecza swojego działania Trybunał dla byłej Jugosławii wydał wyroki skazujące na kary pozbawienia wolności wobec 90 oskarżonych, między innymi Radovana Karadžicia oraz Radko Mladićia. W okresie swojego funkcjonowania organ ten zawarł 17 umów z państwami europejskimi dotyczących przyjęcia do wykonywania kary pozbawienia wolności skazanych przez trybunał na terytorium państw-stron tych porozumień bilateralnych. W konsekwencji faktu, że sygnatariuszami porozumień są wyłącznie państwa europejskie, można oczekiwać pewnej standaryzacji odnośnie do postępowań w zakresie wykonywania kary

22 Por. art. $78 \S 1$ kodeksu karnego oraz art. 46 (1) austriackiego kodeksu karnego (Strafgesetzbuch).

23 Por. decyzję Trybunału dla Rwandy w sprawie o przedterminowe zwolnienie skazanego za udział w zbrodni ludobójstwa Michela Bagaragazy z dnia 24 października 2011 r., sprawa nr ICTR05-86-S, w której pisemnych motywach znajduje się odniesienie do odmiennej praktyki obu trybunałów w zakresie quantum odbytej przez skazanych kary.

24 Decyzja Mechanizmu Rezydualnego w sprawie o przedterminowe zwolnienie Miroslava Bralo z dnia 31 grudnia 2019 r., sprawa nr MICT-14-78-ES, s.13-14.

25 Ibidem. 
pozbawienia wolności, państwa te jako członkowie Rady Europy zobowiązały się między innymi do przestrzegania zaleceń Komitetu Rady Ministrów do państw członkowskich Rady Europy w sprawie Europejskich Reguł Więziennych ${ }^{26}$.

Trybunał dla Rwandy, który funkcjonował o cztery lata krócej niż swój pierwowzór, skazał na karę pozbawienia wolności 61 oskarżonych, w tym Théoneste Bagosorę. Organ ten zawarł osiem porozumień dwustronnych z państwami afrykańskimi i europejskimi w przedmiocie przekazania skazanych do wykonania kary pozbawienia wolności na terytorium państwa-strony umowy. W tych przypadkach zatem należy spodziewać się znaczących różnic odnośnie do przebiegu procesu wykonywania kary pozbawienia wolności wobec skazanych, mimo że państwa kontrahenci objęte są rekomendacjami zawartymi w treści Reguł Mandeli ${ }^{27}$.

Jak wynika $z$ dostępnych danych statystycznych, 85\% osób skazanych przez oba trybunały uzyskało przedterminowe zwolnienie ${ }^{28}$.

\section{Postępowanie w przedmiocie udzielenia przedterminowego zwolnienia przez Mechanizm Rezydualny ONZ}

Mechanizm Rezydualny jest sukcesorem obu trybunałów w zakresie prowadzenia postępowań, także karno-wykonawczych (w tym podejmowania decyzji w przedmiocie przedterminowego zwolnienia). Organ ten rozpoczął przejmowanie spraw od Trybunału dla Rwandy od lipca 2012 roku, a Trybunału dla byłej Jugosławii od lipca 2013 roku $^{29}$ (składa się przy tym z dwóch wydziałów - odpowiednio z siedzibą w Aruszy i w Hadze). Po zakończeniu pracy obu trybunałów ad hoc pozostały kwestie wymagające kontynuowania postępowania, w związku z czym, jak stwierdził Theodor Meron (ówczesny prezes Mechanizmu Rezydualnego ONZ) na forum Rady Bezpieczeństwa w dniu 7 czerwca 2012 roku, zakończenie funkcjonowania obu trybunałów ad hoc ,nie otworzy drogi do bezkarności" ${ }^{30}$. Mechanizm Rezydualny rozpoczął wydawanie decyzji w przedmiocie udzielania lub odmowy warunkowego przedterminowego zwolnienia dopiero od

${ }^{26}$ Europejskie Reguły Więzienne, Rada Europy Komitet Ministrów zalecenia Rec (2006)2, https://www.sw.gov.pl/assets/98/29/13/4d0aa81edd3ddc0d1132flbde154ab564484eb10.pdf (dostęp: 1.06.2020).

27 Wzorcowe Reguły Minimalne Organizacji Narodów Zjednoczonych dotyczące Postępowania z Więźniami (Reguły Mandeli), https://cdn.penalreform.org/wp-content/uploads/1957/06/ Reguly_Mandeli.pdf (dostęp: 1.06.2020).

${ }^{28} \mathrm{https}$ //www.justiceinfo.net/en/tribunals/ictr/41861-early-release-of-ictr-convicts-thepractice-beyond-the-outrage.html (dostęp: 1.06.2020).

29 J.H. Choi, Early release in international criminal law, „The Yale Law Journal” 2014, nr 123 , s. 1792.

${ }^{30} \mathrm{http}$ ://www.unic.un.org.pl/prawa-czlowieka/mechanizm-narodow-zjednoczonych-dlamiedzynarodowych-trybunalow-karnych/3142\# (dostęp: 1.06.2020). 
$2019 \mathrm{roku}^{31}$. Co istotne, stosując ją wraz z obowiązkami probacyjnymi ${ }^{32}$. Zaadaptował też linię orzeczniczą Trybunału Karnego dla byłej Jugosławii oraz Trybunału dla Rwandy dotyczącą warunków ubiegania się przez skazanego o przedterminowe zwolnienie z kary pozbawienia wolności, w szczególności wymogu odbycia quantum kary. Z tym jednak zastrzeżeniem, że Prezydent Mechanizmu, rozpoznając wniosek o przedterminowe zwolnienie skazanego z kary pozbawienia wolności, powinien stosować jednakowe przesłanki przy podejmowaniu tej decyzji w odniesieniu do skazanych przez Trybunał do spraw byłej Jugosławii, Trybunał dla Rwandy lub Mechanizm Rezydualny ${ }^{33}$.

Zgodnie $\mathrm{z}$ art. 25 ust. 2 Statutu ${ }^{34}$ Mechanizm Rezydualny nadzoruje wykonanie wyroków skazujących wydanych przez Międzynarodowy Trybunał dla Rwandy, Międzynarodowy Trybunał dla byłej Jugosławii lub Mechanizm Rezydualny, a ponadto kontroluje wykonanie postanowień umów dotyczących wykonywania orzeczonych przez wymienione organy kar pozbawienia wolności zawartych przez ONZ z państwami członkowskimi ${ }^{35}$. Statut Mechanizmu w treści art. 26 expilicite wskazuje, iż decyzja w przedmiocie udzielenia skazanemu przez trybunały ad hoc lub Mechanizm Rezydualny przedterminowego zwolnienia należy do wyłącznej kompetencji właściwego organu międzynarodowego, aktualnie do Prezesa Mechanizmu Rezydualnego. Statut Mechanizmu Rezydualnego nie przewiduje udziału organów państwa członkowskiego ONZ, na którego terytorium kara jest wykonywana, w tej procedurze ${ }^{36}$. Decyzję w tym przedmiocie Prezes Mechanizmu Rezydualnego podejmuje, kierując się dobrem wymiaru sprawiedliwości (interests of justice) oraz ogólnymi zasadami prawa (general principles of law). Należy zauważyć, że żadne z przepisów statutowych nie odnoszą się explicite do udzielenia skazanym przedterminowego zwolnienia. Wprawdzie podczas prac nad Statutem Mechanizmu Rezydualnego zgłoszono potrzebę uregulowania normatywnego tej instytucji, w ostatecznej wersji jednak nie umieszczono jej w treści

31 Decyzja Mechanizmu Rezydualnego w sprawie przedterminowego zwolnienia z dnia 16 stycznia 2019 r. dotycząca Valentina Ćorić, wniosek nr MICT-17-112-ES.4; decyzja Mechanizmu Rezydualnego w sprawie przedterminowego zwolnienia z dnia 7 styczna 2019 r. dotycząca Aloysa Simby, wniosek nr MICT-14-62-ES.1.

32 Por. obowiązki probacyjne nałożone na Valentina Ćorića w okresie kary, która pozostała do odbycia: zakaz kontaktowania się z pokrzywdzonymi lub świadkami w sprawie; zakaz angażowania się $\mathrm{w}$ aktywności o charakterze politycznym, zakaz popełniania przestępstw, posługiwania się bronią, odnoszenia się do postępowania karnego, w którym występował jako oskarżony, ibidem.

33 B. Holá, J. van Wijk, op. cit., s. 122.

34 Statut jest załącznikiem do rezolucji Rady Bezpieczeństwa ONZ z dnia 22 grudnia 2010 r., nr 1966, https://www.icty.org/x/file/About/Reports\%20and\%20Publications/ResidualMechanism/10 1222_sc_res1966_residualmechanism_en.pdf (dostęp: 1.12.2020).

${ }_{35} \bar{Z}$ godnie z treścią rezolucji Rady Bezpieczeństwa 1966 (2010) z dnia 22 grudnia 2010 r. (S/RES/1996) wszystkie umowy z państwami członkowskim ONZ obowiązujące w dacie powołania Mechanizmu Rezydualnego nadal pozostają w mocy i powinny być stosowane.

36 Por. decyzja Prezydenta Mechanizmu z dnia 31 grudnia 2019 r. w sprawie Miroslav Bralo. 
postanowień Statutu ${ }^{37}$. Mimo nabytych doświadczeń na gruncie wieloletniego funkcjonowania obu przedmiotowych trybunałów ad hoc nie doszło zatem do uzupełnienia podstawy prawnej w tym zakresie.

Postanowienia Statutu są uszczegółowione Regułami Postępowania i Dowodowymi Mechanizmu Rezydualnego ( $\mathrm{z}$ ang. Rules od Procedure and Evidence, dalej: Reguły). Zgodnie z art. 128 Reguł Mechanizm Rezydualny sprawuje nadzór nad procesem wykonywania kar pozbawienia wolności w państwach, które przyjęły skazanych przez trybunały dla Rwandy, byłej Jugosławii lub Mechanizm Rezydualny. Wszelkie decyzje dotyczące procesu odbywania kary należą zatem do kompetencji Mechanizmu Rezydualnego (uprzednio zaś wskazanych trybunałów). Każde państwo, które przyjęło skazanego przez Międzynarodowy Trybunał Karny dla byłej Jugosławii czy też dla Rwandy lub Mechanizm Rezydualny do wykonania kary pozbawienia wolności na swoim terytorium, jest zobowiązane notyfikować Prezesowi Mechanizmu Rezydualnego fakt, że skazany nabył uprawnienia do wystąpienia o ułaskawienie, do zamiany kary na karę łagodniejszego rodzaju lub do ubiegania się o przedterminowe zwolnienie, na co najmniej na 45 dni przed formalnym nabyciem przez sprawcę tychże uprawnień (art. 149 Reguł w zw. z § 3 Wskazówek Praktycznych wydanych przez Prezesa Mechanizmu Rezydualnego ${ }^{38}$ ). Sąd powszechny państwa przyjmującego ani inny organ krajowego wymiaru sprawiedliwości nie ma uprawnień do rozstrzygania w wymienionych sprawach ani też nie jest formalnie uprawniony do wydawania opinii w zakresie ułaskawienia, zamiany kary pozbawienia wolności na karę łagodniejszego rodzaju lub przedterminowego zwolnienia. W przypadku wydania takiego orzeczenia nie może ono wejść do obrotu prawnego z uwagi na niedopuszczalność orzekania sądów krajowych (w Polsce powinno dojść do odmowy wszczęcia lub do umorzenia takiego postępowania na podstawie art. 17 § 1 pkt 8 k.p.k.).

Prezydent Mechanizmu podejmuje decyzje w wymienionym przedmiocie po uzyskaniu wniosku pochodzącego od państwa, na którego terytorium przebywa skazany. Jest też możliwe złożenie takiego wniosku do Prezesa Mechanizmu bezpośrednio przez zainteresowanego skazanego (wówczas należy żądać potwierdzenia od państwa wykonującego karę pozbawienia wolności, że skazany faktycznie nabył uprawnienia zgodnie z prawem krajowym do skorzystania $\mathrm{z}$ wymienionych dobrodziejstw). Po wpłynięciu wniosku od państwa Sekretariat Mechanizmu Rezydualnego powinien poinformować skazanego, że przysługuje mu prawo do ubiegania się o ułaskawienie, złagodzenie kary lub przedterminowe zwolnienie. Skazany w ciągu 10 dni od przekazania mu tych informacji może się ustosunkować do wszelkich kwestii bądź przez wniesienie pisma, bądź przez

37 J.H. Choi, op. cit., s. 1799.

38 Practice Directions on the procedure for the determination of applications for pardon, commutation of sentence and early release of persons convicted by the ICTR, the ICTY and the Mechanism (rev.3), wydane w dniu 15 maja 2020 r., https://www.irmct.org/en/basic-documents/practicedirections (dostęp: 1.12.2020). 
wysłuchanie w formie rozmowy telefonicznej lub wideokonferencji ( $\$ 6$ Wskazówek Praktycznych).

Następnie Sekretariat Mechanizmu żąda między innymi informacji od organów państwa, na którego terytorium kara jest wykonywana, na temat przebiegu kary, na przykład o zachowaniu skazanego podczas wykonywania wobec niego kary pozbawienia wolności, warunkch odbywania kary i prowadzonych oddziaływaniach penitencjarnych, opinii penitencjarno-psychologicznych lub psychiatrycznych dotyczących stanu psychicznego skazanego ( $\$ 4$ b Wskazówek Praktycznych). Ponadto prokurator Mechanizmu Rezydualnego powinien przedłożyć szczegółowy raport odnoszący się do współpracy (lub jej braku) ze strony skazanego (substantial cooperation) oraz na temat znaczenia tej współpracy dla przebiegu postępowania ( $\$ 3$ ust. 4 a-c Wskazówek Praktycznych). Za przejaw współpracy z organami wymiaru sprawiedliwości przyjmuje się nie tylko pozytywną postawę skazanego podczas odbywania orzeczonej wobec niego kary i dostarczanie informacji odnośnie do popełnionych zbrodni, ale także zachowania wcześniejsze, to jest na etapie toczącego się postępowania przygotowawczego oraz postępowania przed trybunałami w przedmiocie ustalenia odpowiedzialności karnej, a w szczególności złożenie wówczas przez sprawcę wniosku o dobrowolne poddanie się karze (plea guilty) czy też przyznanie się do winy w trakcie toczącego się postępowania.

Podkreślenia tu wymaga, że w okresie, gdy obowiązki prezesa Międzynarodowego Trybunału dla byłej Jugosławii pełnił sędzia Theodor Meron, informacje przedkładane przez prokuratora tego trybunału mogły dotyczyć wyłącznie wymienionej kwestii. Tę linię kontynuowano pod rządami Mechanizmu Rezydualnego, gdy sędzia Meron został powołany na stanowisko prezesa Mechanizmu ${ }^{39}$. Odmienna praktyka natomiast wykształciła się na gruncie orzecznictwa Trybunału dla Rwandy, gdzie przyjmowano, że prokurator może przedstawić swoje stanowisko w przedmiocie wniosku o przedterminowe zwolnienie czy innej rozpoznawanej kwestii (poprzeć wniosek bądź się sprzeciwić wnioskowi).

Prezes Mechanizmu Rezydualnego co do zasady konsultuje podejmowane rozstrzygnięcie merytoryczne z sędziami, którzy uczestniczyli w wydaniu wyroku skazującego, jeżeli w czasie rozpoznawania wniosku w dalszym ciągu pełnią funkcję sędziów Mechanizmu. Jeżeli konsultacja z sędziami, którzy uczestniczyli w skazaniu, nie jest możliwa (gdyż na przykład sędziowie biorący udział w wydaniu orzeczenia skazującego utracili status sędziów Mechanizmu) w opiniowaniu uczestniczą co najmniej dwaj sędziowie Mechanizmu. Prezes Mechanizmu Rezydualnego przekazuje im wszelkie istotne dla sprawy informacje i wyznacza czas potrzebny do zapoznania się z nimi oraz do wydania opinii ( 7 Wskazówek

39 Por. uzasadnienie jednej z ostatnich decyzji (i przytoczone tam argumenty) podjętych przez Theodora Merona jako Prezesa Mechanizmu w sprawie o przedterminowe zwolnienie skazanego Valentina Ćorića z dnia 16 stycznia 2019 r. 
Praktycznych). Jednakże Prezes Mechanizmu Rezydualnego nie jest związany wydaną przez sędziów-konsultantów opinią.

Zaznaczyć trzeba, że żaden z przepisów odnoszących się do przedmiotowej problematyki nie przewiduje zasięgania opinii pokrzywdzonych $\mathrm{w}$ kwestiach związanych z ubieganiem się o dobrodziejstwo przedterminowego zwolnienia przez skazanych na mocy orzeczeń trybunałów lub Mechanizmu Rezydualnego.

Prezes Mechanizmu, rozważając kwestię udzielenia przedterminowego zwolnienia skazanemu, uwzględnia - (art. 151 Reguł) — wagę popełnionego przezeń przestępstwa lub przestępstw, w związku z którymi doszło do skazania, standardy postępowania wobec skazanych znajdujących się w analogicznej sytuacji jak osoba, której wniosek dotyczy, postępy skazanego w resocjalizacji, przejawy istotnej współpracy skazanego z prokuratorem Mechanizmu oraz inne okoliczności (jak na przykład stan zdrowia skazanego, wpływ udzielenia dobrodziejstwa na pokrzywdzonych i sytuację świadków) ${ }^{40}$.

Podkreślić wypada, że w praktyce interpretacja wyrażenia ,standardy postępowania wobec skazanych znajdujących się w analogicznej sytuacji jak wnioskodawca" polegała na zaadaptowaniu przez Mechanizm Rezydualny koncepcji quantum odbycia dwu trzecich kary pozbawienia wolności jako przesłanki formalnej do ubiegania się o przedterminowe zwolnienie ${ }^{41}$. Przesłanka formalna znajduje swoje zastosowanie zarówno do skazanych przekazanych do odbycia kary pozbawienia wolności na terytorium państw członkowskich ONZ, które podpisały stosowne umowy w tym przedmiocie, jak i przebywających w jednostkach penitencjarnych znajdujących się pod kontrolą ONZ, zlokalizowanych w Aruszy i Hadze. Oczywiste jest, że dopiero po stwierdzeniu występowania tej przesłanki można przejść do dalszego badania sprawy. Spełnienie formalnej przesłanki nie przesądza jednak o udzieleniu dobrodziejstwa przedterminowego zwolnienia. Pozostałe przesłanki materialne mają charakter równoważny, nie wszystkie muszą być spełnione, aby doszło do wydania decyzji zgodnej z wnioskiem, mogą mieć charakter przeważający ${ }^{42}$. W praktyce orzeczniczej Międzynarodowego Trybunału dla Rwandy po raz pierwszy wyrażono przekonanie, że wzgląd na zasadę humanitaryzmu może przesądzić o wydaniu pozytywnego rozstrzygnięcia w sprawie mimo niespełnienia się przesłanek materialnych (na przykład ze względu na zły stan zdrowia skazanego, wymagającego opieki medycznej dostępnej wyłącznie w warunkach wolnościowych). Pogląd ten został podzielony

40 Por. decyzja Prezesa Trybunału dla byłej Jugosławii w sprawie przedterminowego zwolnienia Dragana Zelenovića z dnia 30 listopada 2012 r., skarga nr IT-96-23/2-ES; decyzja Prezesa Trybunału dla byłej Jugosławii w sprawie przedterminowego zwolnienia Ranko Češića $\mathrm{z}$ dnia 28 maja 2014 r., skarga nr MICT-14-66-ES.

41 Por. np. A. Merrylees, Two-thirds and you're out? The practice of early release at the ICTY and ICC, in light of the goals of international criminal justice, „Amsterdam Law Forum” 8, 2016, nr 2, s. 71.

42 Por. orzeczenie Prezydenta Mechanizmu z dnia 31 grudnia 2019 r. w sprawie Miroslav Bralo. 
także w orzecznictwie Międzynarodowego Trybunału dla byłej Jugosławii ${ }^{43}$. W aktualnym stanie rzeczy na tę przesłankę usiłowano powoływać się w kontekście sytuacji pandemicznej związanej z zagrożeniem epidemią wywołaną przez wirus SARS-CoV-2. W każdym takim przypadku Prezes Mechanizmu ustalał w porozumieniu z państwem przyjmującym karę do wykonania, czy zapewnione są skazanemu bezpieczne warunki jej odbycia. Jak dotąd państwa skutecznie wykazywały podejmowanie wszelkich niezbędnych działań prewencyjnych na terenie swoich jednostek penitencjarnych ${ }^{44}$.

Decyzja powinna zapaść najpóźniej na siedem dni przed spełnieniem przesłanek formalnych do ubiegania się przez skazanego o ułaskawienie, złagodzenie kary lub przedterminowe zwolnienie i jest jawna, jeżeli Prezes Mechanizmu nie postanowi inaczej ( $\S 10$ Wskazówek Praktycznych). W przypadkach odmowy udzielenia przedterminowego zwolnienia Prezes Mechanizmu Rezydualnego określa termin, po którego upływie skazany może ponownie złożyć wniosek w tym przedmiocie, chyba że przepisy obowiązujące w państwie wykonania kary wskazują takie okresy ( $\$ 11$ Wskazówek Praktycznych). Decyzja Prezesa Mechanizmu ma charakter dyskrecjonalny, podejmowany zgodnie z zasadą swobodnego uznania. Jest ona ostateczna i podlega doręczeniu skazanemu, organom państwa miejsca wykonania kary oraz innym zainteresowanym osobom (§ 13 i § 14 Wskazówek Praktycznych). Gdyby państwo przyjmujące orzeczenie do wykonania nie zgadzało się z treścią rozstrzygnięcia lub gdyby jego treść była sprzeczna $\mathrm{z}$ treścią obowiązujących w tym państwie przepisów prawnych, Prezes Mechanizmu postanawia o przetransportowaniu skazanego do innego państwa w celu odbycia tam pozostałej do wykonania części kary (§ 12 Wskazówek Praktycznych).

\section{Konkluzje}

Aktualnie funkcję międzynarodowego sądu karnego pełni Międzynarodowy Trybunał Karny z siedzibą w Hadze. Ponadto działa Międzynarodowy Trybunał Rezydualny ONZ, który zastąpił funkcjonujące do niedawna w tym obszarze dwa sądy międzynarodowe ustanowione na mocy decyzji Rady Bezpieczeństwa ONZ do osądzenia zbrodni popełnionych w byłej Jugosławii i Rwandzie - Międzynarodowy Trybunał Karny dla byłej Jugosławii oraz Międzynarodowy Trybunał Karny dla Rwandy.

Przeprowadzone ostatnio badania empiryczne ujawniły, że ponad dwie trzecie skazanych przez Międzynarodowy Trybunał Karny dla Jugosławii oraz

43 Provisional release, release at advanced stages of proceedings and final release at international criminal courts and tribunals, ICC \& ICL Programme Discussion Paper Series, London 2019, s. 49 n.

44 Por. decyzja Prezesa Mechanizmu Rezydualnego z dnia 17 września 2020 r. w sprawie przedterminowego zwolnienia z kary pozbawienia wolności Laurenta Semanzy, MICT-13-36-ES.2. 
Międzynarodowy Trybunał Karny Rwandy skorzystało z dobrodziejstwa warunkowego przedterminowego zwolnienia z kary pozbawienia wolności nieobwarowaną żadnymi obowiązkami probacyjnymi. Stosując tę instytucję, jak wynika z treści decyzji przedmiotowych trybunałów lub Mechanizmu Rezydualnego, organy te zasadniczo koncentrowały się na spełnieniu się w sprawie formalnej przesłanki odbycia wymaganego quantum kary oraz poprawnym zachowaniu się skazanego podczas jej wykonywania ${ }^{45}$. W uzasadnieniach swoich decyzji w przedmiocie udzielenia warunkowego zwolnienia trybunały ad hoc bardzo często nawiązywały do resocjalizacyjnego celu orzeczonej kary pozbawienia wolności ${ }^{46}$. Postępy w resocjalizacji skazanego są jedną z istotniejszych przesłanek wcześniejszego zwolnienia z kary także w praktyce Mechanizmu Rezydualnego. Resocjalizacja rozumiana jest jako skuteczna reintegracja społeczna skazanego, pozwalająca mu na kontynuowanie życia w warunkach wolnościowych w sposób zgodny z obowiązującym porządkiem prawnym. Aktualny prezes Mechanizmu sędzia Carmel Aigus słusznie zauważył w tym kontekście, że proces resocjalizacji osób skazanych za przestępstwa ludobójstwa, przeciwko pokojowi czy przestępstwa wojenne musi się różnić ze względu na charakter przypisanych im czynów od procesu resocjalizacji, w którym uczestniczą skazani za inne przestępstwa. Skuteczny model powinno jednak w tym zakresie wypracować państwo przyjmujące orzeczenie trybunałów ad hoc lub Mechanizmu do wykonania. Ani trybunały, ani Mechanizm, który je zastąpił, nie wypracowały bowiem w tej mierze precyzyjnej i spójnej koncepcji resocjalizacji. Zauważyć przy tym należy, że finalny efekt oddziaływań resocjalizacyjnych musi być taki sam jak w przypadku sprawców innych czynów zabronionych, powinien być to sukces w postaci efektywnej reintegracji ze społeczeństwem skazanego za ludobójstwo, przestępstwa przeciwko ludzkości lub zbrodnie wojenne.

\section{Bibliografa}

Choi J.H., Early release in international criminal law, „The Yale Law Journal” 2014, nr 123.

Domagała A., Ściganie i karanie sprawców gwaltu i przemocy seksualnej podczas konfliktów zbrojnych po zakończeniu zimnej wojny, „Wrocławskie Studia Politologiczne” 2011, nr 12.

Gozani D., Beginning to learn how to end: lessons on completion strategies, Residual Mechanism and legacy considerations from ad hoc international tribunals to the international criminal court, „Loyola of Los Angeles International and Comparative Law Review” 4, 2015, nr 1.

Heidrich D., Przyszłość międzynarodowych trybunałów karnych ad hoc. Strategie zakończenia oraz rozwiązania rezydualne, ze szczególnym uwzględnieniem Międzynarodowego Trybunału Karnego dla bytej Jugostawii, „Studia Europejskie” 2013, nr 3.

${ }^{45} \mathrm{https}$ //www.justiceinfo.net/en/tribunals/ictr/41861-early-release-of-ictr-convicts-the-pra ctice-beyond-the-outrage.html (dostęp: 10.10.2020).

46 B. Holá et al., op. cit., s. 2. 
Holá B., Wijk J. van, Life after conviction at International Criminal Tribunals, „Journal of International Criminal Justice" 12, 2014.

Holá B., Wijk J. van, Constantini F., Korhonnen A., Does remorse count? ICTY Convict's reflections on their crimes in early release decisions, „International Criminal Justice Review” 28, 2018, nr 4.

Karski K., Świętońska D., Proces przed Międzynarodowym Trybunatem Wojskowym dla Dalekiego Wschodu i jego miejsce w świadomości historycznej Japończyków, „Gdańskie Studia Azji Wschodniej" 2013, nr 4.

Merrylees A., Two-thirds and you're out? The practice of early release at the ICTY and ICC, in light of the goals of international criminal justice, „Amsterdam Law Forum” 8, 2016, nr 2.

Olesiuk-Okomska M., Przestępstwa międzynarodowe podlegajace rozpoznaniu przez międzynarodowe trybunaty karne, ,International Journal of Legal Studies” 2017, nr 2.

Pospieszalski K.M., Wyrok Norymberski (zasady prawne), „Przegląd Zachodni” 1948, nr 2.

Provisional release, release at advanced stages of proceedings and final release at international criminal courts and tribunals, ICC \& ICL Programme Discussion Paper Series, London 2019.

Spychalska A., Mechanizmy zbrodni ludobójstwa na przykładzie Rwandy, [w:] Varia doctrinalia, red. Ł. Machaj, Wrocław 2012.

Śliwa R., Międzynarodowy trybunat do spraw ścigania osób odpowiedzialnych za łamanie międzynarodowych praw czlowieka na terytorium byłej Jugosławii począwszy od 1991 r., [w:] Bałkany u progu zjednoczonej Europy, red. P. Czubik, Kraków 2008.

\section{Wykaz aktów prawnych}

Europejskie Reguły Więzienne, Rada Europy Komitet Ministrów zalecenia Rec (2006)2.

Karta Narodów Zjednoczonych podpisana w dniu 26 czerwca 1945 r. w San Francisco, Dz.U. z 1947 r. $\mathrm{Nr} 23$, poz. 90.

Rezolucja Rady Bezpieczeństwa nr 808 z dnia 22 lutego 1993 r., SC/Res/22.02.1993.

Rezolucja Rady Bezpieczeństwa nr 827 z dnia 25 maja 1993 r., SC/Res/25.05.1993.

Rezolucja Rady Bezpieczeństwa nr 1966 z dnia 22 grudnia 2010 r., SC/Res/22.12.2010.

Rzymski Statut Międzynarodowego Trybunału Karnego sporządzony w Rzymie dnia 17 lipca 1998 r., Dz.U. z 2003 r. Nr 78, poz. 708.

Statut Międzynarodowego Trybunału do Spraw Ścigania Osób Odpowiedzialnych za Poważne Naruszenia Międzynarodowego Prawa Humanitarnego na Terytorium byłej Jugosławii od 1991 roku, przyjęty dnia 25 maja 1997 roku Rezolucją Rady Bezpieczeństwa ONZ 827 z późn. zmianami - tekst jednolity.

Statut Międzynarodowego Trybunału Karnego do Sądzenia Osób Odpowiedzialnych za Ludobójstwo i Inne Poważne Naruszenia Międzynarodowego Prawa Humanitarnego Popełnione na Terytorium Rwandy oraz Obywateli Rwandy Odpowiedzialnych za Ludobójstwo oraz Inne Takie Naruszenia Popełnione na Terytorium Państw Sąsiednich pomiędzy 1 stycznia 1994 r. do 31 grudnia 1994 r., przyjęty dnia 8 listopada 1994 r. rezolucją Rady Bezpieczeństwa ONZ nr 955 z późn. zmianami.

Wzorcowe Reguły Minimalne Organizacji Narodów Zjednoczonych dotyczące Postępowania z Więźniami (Reguły Mandeli), rezolucja przyjęta przez Zgromadzenie Ogólne ONZ w dniu 17 grudnia 2015 r., $\mathrm{nr} 70 / 175$.

Zalecenie nr R (2003)22 Komitetu Ministrów do Państw Członkowskich Rady Europy w sprawie zwolnienia warunkowego. 


\section{Wykaz orzeczeń}

Decyzja Mechanizmu Rezydualnego w sprawie przedterminowego zwolnienia z dnia 7 stycznia 2019 r. dotycząca Aloysa Simby, wniosek nr MICT-14-62-ES.1.

Decyzja Mechanizmu Rezydualnego w sprawie przedterminowego zwolnienia w sprawie o przedterminowe zwolnienie skazanego Valentina Ćorić z dnia 16 stycznia 2019 r., MICT-17-112-ES.4.

Decyzja Prezesa Mechanizmu Rezydualnego w sprawie o przedterminowe zwolnienie Miroslava Bralo z dnia 31 grudnia 2019 r., sprawa nr MICT-14-78-ES, s.13-14.

Decyzja Prezesa Mechanizmu Rezydualnego z dnia 17 września 2020 r. w sprawie przedterminowego zwolnienia z kary pozbawienia wolności Laurenta Semanzy, MICT -13-36-ES.2.

Decyzja Prezesa Trybunału dla byłej Jugosławii w sprawie przedterminowego zwolnienia Dragana Zelenovića z dnia 30 listopada 2012 r., skarga nr IT-96-23/2-ES;

Decyzja Prezesa Trybunału dla byłej Jugosławii w sprawie przedterminowego zwolnienia Ranko Češića z dnia 28 maja 2014 r., skarga nr MICT-14-66-ES.

Decyzja Prezesa Trybunału dla Rwandy w sprawie o przedterminowe zwolnienie skazanego za udział w zbrodni ludobójstwa Michela Bagaragazy z dnia 24 października 2011 r., sprawa nr ICTR-05-86-S.

\section{Źródła internetowe}

https://cdn.penalreform.org/wp-content/uploads/1957/06/Reguly_Mandeli.pdf.

https://www.icty.org/x/cases/aleksovski/cis/en/cis_aleksovski_en.pdf.

https://www.icty.org/en/press/president-icty-grants-release-dragan-kolundzija.

https://www.icyty.org/en/press/president-icty-orders-release-milojica-kos.

https://www.sw.gov.pl/assets/98/29/13/4d0aa81edd3ddc0d1132f1bde154ab564484eb10.pdf.

https://www.icty.org/x/file/About/Reports\%20and\%20Publications/ResidualMechanism/101222_ sc_res1966_residualmechanism_en.pdf.

http://www.unic.un.org.pl/prawa-czlowieka/mechanizm-narodow-zjednoczonych-dla-miedzy narodowych-trybunalow-karnych/3142\#.

https://www.irmct.org/en/basic-documents/practice-directions.

https://www.irmct.org/sites/default/files/documents/MICT-1-Rev.6\%20\%28E\%29.pdf.

https://www.justiceinfo.net/en/tribunals/ictr/41861-early-release-of-ictr-convicts-the-practicebeyond-the-outrage.html. 